\title{
Polymorphism in metal complexes of thiazole-4-carboxylic acid
}

\author{
Natthaya Meundaeng ${ }^{1} \cdot$ Apinpus Rujiwatra ${ }^{1}$ Timothy J. Prior ${ }^{2}$
}

Received: 22 June 2016/ Accepted: 30 June 2016/Published online: 26 July 2016

(c) The Author(s) 2016. This article is published with open access at Springerlink.com

\begin{abstract}
Five new molecular complexes of chemical formula $\left[\mathrm{M}(4-\mathrm{tza})_{2}\left(\mathrm{H}_{2} \mathrm{O}\right)_{2}\right](\mathrm{M}=\mathrm{Co}, \mathrm{Ni}$, or $\mathrm{Cu})$ and a complex of $\left[\mathrm{Cu}(4-\mathrm{tza})_{2}\right] \cdot 4 \mathrm{H}_{2} \mathrm{O}$ using thiazole-4-carboxylic acid (4-tza) as the ligand have been successfully synthesized and structurally characterized by single crystal X-ray diffraction. Two district polymorphs $(\alpha$ and $\beta)$ are found for both $\left[\mathrm{Co}(4-\mathrm{tza})_{2}\left(\mathrm{H}_{2} \mathrm{O}\right)_{2}\right]$ and $\left[\mathrm{Ni}(4-\mathrm{tza})_{2}\left(\mathrm{H}_{2} \mathrm{O}\right)_{2}\right]$. The effects of solvent composition and temperature on the formation of these polymorphs have been investigated and phase behaviour of the polymorphs was studied through $\mathrm{X}$-ray powder diffraction. Unlike the complexes of Co and $\mathrm{Ni},\left[\mathrm{Cu}(4-\mathrm{tza})_{2}\left(\mathrm{H}_{2} \mathrm{O}\right)_{2}\right]$ does not display polymorphism but exhibits irreversible structural transformation from $\left[\mathrm{Cu}(4-\mathrm{tza})_{2}\left(\mathrm{H}_{2} \mathrm{O}\right)_{2}\right]$ to the dehydrated form, $\left[\mathrm{Cu}(4-\mathrm{tza})_{2}\right]$, upon heating.
\end{abstract}

\section{Introduction}

Polymorphism is the ability of a pure compound to adopt more than one packing arrangement in the solid state [1]. The occurrence of polymorphic modifications in molecular compounds is manifested not just as a consequence of minimum free energy of the crystalline phases but also by kinetics of crystal nucleation and growth [2,3]. This phenomenon is of particular importance in the pharmaceutical industry since the activity of a drug might change abruptly

Timothy J. Prior

t.prior@hull.ac.uk

1 Department of Chemistry, Faculty of Science, Chiang Mai University, Chiang Mai 50200, Thailand

2 Department of Chemistry, University of Hull, Kingston upon Hull HU6 7RX, UK from one polymorph to another $[4,5]$. The preferential growth of a particular from can often be rationalized by consideration of conformational equilibria or changes in patterns of weak intermolecular interactions which are able to strongly influence the final packing structure $[2,6,7]$. The comparison between different polymorphs could provide an ideal approach for understanding the structureproperty relationships in molecular solids because property differences between polymorphs result from different molecular packing and/or conformation and not from different chemical compositions [8, 9]. Therefore, controlling crystal formation of a specific polymorph has recently become one of the major activities and of high practical interest in the field of crystal engineering, particularly the characterization of polymorphs, the conversion of one into another, and the ways in which solid state properties of polymorphs vary with structure [10-12].

Unlike purely organic systems, it is rather unusual to observe polymorphism in inorganic compounds, in particular if the two or more polymorphs are stable at the same temperature. The difference in crystal packing may be accompanied by a change in colour. For example, the simple complex $\mathrm{Pt}\left(2,2^{\prime}\right.$-bipyridine $) \mathrm{Cl}_{2}$ exists as two different crystal forms under ambient conditions depending on the solvent employed: a red form [13] that crystallises in space group $\mathrm{Cmcm}$ and a yellow form [14] that adopts space group Pbca.

Thiazolecarboxylic acids have attracted attention as potential ligands to first row transition metals. When deprotonated, thiazole-2-carboxylic acid and thiazole-4carboxylic acid can form five-membered chelating rings through the nitrogen atom and the carboxylate. Thiazole-5carboxylic acid cannot form $[\mathrm{N}, \mathrm{O}]$ chelates because of the separation of the nitrogen and the carboxylic acids, but might form $[\mathrm{S}, \mathrm{O}]$ chelates. The chemistry of these and 
similar ligands has been reviewed recently [15] and several complexes have been reported [16, 17].

Herein, we describe the syntheses of five molecular structures with chemical formula $\left[\mathrm{M}(4-\mathrm{tza})_{2}\left(\mathrm{H}_{2} \mathrm{O}\right)_{2}\right]$ (where $\mathrm{M}$ is Co for complex $\mathbf{I}$, Ni for complex $\mathbf{I I}$ or $\mathrm{Cu}$ for complex III, respectively) and a complex of $\left[\mathrm{Cu}(4-\mathrm{tza})_{2}\right]-$ $4 \mathrm{H}_{2} \mathrm{O}$ (IV) with thiazole-4-carboxylic acid (4-tza) and the selective formation of polymorphs for $\left[\mathrm{Co}(4-\mathrm{tza})_{2}\left(\mathrm{H}_{2} \mathrm{O}\right)_{2}\right]$ (I) and $\left[\mathrm{Ni}(4-\mathrm{tza})_{2}\left(\mathrm{H}_{2} \mathrm{O}\right)_{2}\right]$ (II). Interestingly, the results reveal a rare example of an inorganic compound that exhibits two stable but distinct crystal structures under the same conditions without ready interconversion. The crystal packing is dictated by synthetic conditions including solvent compositions and temperature and the extremely stable nature of the two polymorphs does not allow interconversion between the two different crystal structures once formed within processing parameters investigated in this study.

\section{Experimental}

\section{Materials and instruments}

Chemical reagents were purchased commercially and were used as received without further purification; $\mathrm{CoSO}_{4} \cdot 7 \mathrm{H}_{2} \mathrm{O}$ (Alfa Aesar, $98 \%$ ), $\mathrm{Ni}\left(\mathrm{SO}_{4}\right) \cdot 6 \mathrm{H}_{2} \mathrm{O}$ (BDH Chemicals, $97 \%$ ), $\mathrm{Cu}\left(\mathrm{NO}_{3}\right)_{2} \cdot 2.5 \mathrm{H}_{2} \mathrm{O}$ (Alfa Aesar, $99 \%$ ), thiazole-4carboxylic acid $\left(\mathrm{C}_{4} \mathrm{H}_{3} \mathrm{NO}_{2} \mathrm{~S}\right.$, Apollo Scientific), L-tryptophan $\left(\mathrm{C}_{11} \mathrm{H}_{12} \mathrm{~N}_{2} \mathrm{O}_{2}\right.$, Merck, $99.0 \%$ ), ethanol (VWR Chemicals, $99.97 \%$ ).

Elemental analysis was performed on a FisonsEA1108 CHNS/O Element Analyzer. IR spectra were collected in a range of $4000-600 \mathrm{~cm}^{-1}$, using a Thermo Scientific Nicolet iS5 FT-IR Spectrometer. Thermogravimetric-differential thermal analysis (TG/DTA) was conducted using a TGA/DSC 1 thermogravimetric analyzer instrument with a heating rate of $20{ }^{\circ} \mathrm{C} \mathrm{min}-1$ operating under air. The X-ray powder diffraction (PXRD) experiments were conducted using a PANalytical Empyrean $\mathrm{X}$-ray diffractometer.

\section{Preparation of $\left[\mathrm{Co}(4-\mathrm{tza})_{2}\left(\mathrm{H}_{2} \mathrm{O}\right)_{2}\right](\mathrm{I})$}

$\mathrm{Co}\left(\mathrm{SO}_{4}\right) \cdot 7 \mathrm{H}_{2} \mathrm{O}(0.0281 \mathrm{~g}, 0.100 \mathrm{mmol})$ was dissolved in $1.0 \mathrm{~mL}$ of distilled water and 4-Htza $(0.0129 \mathrm{~g}, 0.1 \mathrm{mmol})$ was dissolved in $4.0 \mathrm{~mL}$ of distilled water (for $\mathbf{I}-\boldsymbol{\alpha}$ polymorph) or $4.0 \mathrm{~mL}$ of a mixed solvent of $40 \%$ ethanol in distilled water (for I- $\boldsymbol{\beta}$ polymorph). The metal solution was slowly added to the ligand solution with constant stirring. The mixture was left at room temperature for several days from which orange crystals were formed. Anal. Calcd for $\left[\mathrm{Co}(4-\mathrm{tza})_{2}\left(\mathrm{H}_{2} \mathrm{O}\right)_{2}\right](\mathbf{I}-\boldsymbol{\alpha})(\%)$ : C, 27.36; H, 2.30; N, 7.98; S,
18.26. Found (\%): C; 27.08; H, 2.30; N, 7.85; S, 18.00. Anal. Calcd for $\left[\mathrm{Co}(4-\mathrm{tza})_{2}\left(\mathrm{H}_{2} \mathrm{O}\right)_{2}\right](\mathbf{I}-\boldsymbol{\beta})(\%)$ : C, 27.36; H, 2.30; N, 7.98; S, 18.26. Found (\%): C; 27.55; H, 2.19; N, 7.81; S, 18.31. Yield based on Co: $90 \%$ for $\mathbf{I}-\alpha$ and $95 \%$ for I- $\boldsymbol{\beta}$. IR $\left(\mathrm{cm}^{-1}\right)$ for $\mathbf{I}-\alpha: 3301 \mathrm{br}, 3133 \mathrm{~m}, 1649 \mathrm{vs}, 1522 \mathrm{~m}$, $1429 \mathrm{~m}, 1323 \mathrm{~m}, 1295 \mathrm{~s}, 1185 \mathrm{~m}, 965 \mathrm{w}, 891 \mathrm{w}, 814 \mathrm{w}, 792 \mathrm{~m}$, $625 \mathrm{w}$. IR $\left(\mathrm{cm}^{-1}\right)$ for I- $\beta$ : $3132 \mathrm{br}, 3118 \mathrm{~m}, 1600 \mathrm{vs}, 1517 \mathrm{~m}$, $1433 \mathrm{~m}, 1340 \mathrm{~s}, 1307 \mathrm{~s}, 1197 \mathrm{w}, 964 \mathrm{~m}, 855 \mathrm{w}, 779 \mathrm{w}, 622 \mathrm{w}$.

\section{Preparation of [Ni(4-tza $\left.)_{2}\left(\mathrm{H}_{2} \mathrm{O}\right)_{2}\right]$ (II)}

To $2.5 \mathrm{~mL}$ of an aqueous solution of 4-Htza (0.0129 g, $0.100 \mathrm{mmol}$ ) in a small glass bottle with a screw cap was added a solution of $\mathrm{Ni}\left(\mathrm{SO}_{4}\right) \cdot 6 \mathrm{H}_{2} \mathrm{O}(0.0262 \mathrm{~g}, 0.100 \mathrm{mmol})$ in $2.5 \mathrm{~mL}$ of distilled water. After the mixture was stirred for an hour, the bottle was left at room temperature. Light blue crystals of II- $\boldsymbol{\alpha}$ polymorph crystallized after several days. II- $\boldsymbol{\beta}$ polymorph can be prepared in the same way as described for II- $\alpha$ but the bottle was sealed and was placed in an oven maintained at $80{ }^{\circ} \mathrm{C}$ for $48 \mathrm{~h}$. The products were washed with water and isolated for $\mathrm{X}$-ray diffraction experiments. Anal. Calcd for [Ni(4-tza $\left.)_{2}\left(\mathrm{H}_{2} \mathrm{O}\right)_{2}\right](\mathbf{I I}-\boldsymbol{\alpha})(\%)$ : C, 27.38; H, 2.30; N, 7.98; S, 18.27. Found (\%): C; 27.59; H, 2.24; N, 7.74; S, 17.99. Anal. Calcd for $\left[\mathrm{Co}(4-\mathrm{tza})_{2}\left(\mathrm{H}_{2} \mathrm{O}\right)_{2}\right](\mathbf{I I}-\boldsymbol{\beta})$ (\%): C, 27.38; H, 2.30; N, 7.98; S, 18.27. Found (\%): C; $27.64 ; \mathrm{H}, 2.17 ; \mathrm{N}, 7.82 ; \mathrm{S}, 18.00$. Yield based on Ni: $95 \%$ for II- $\boldsymbol{\alpha}$ and $97 \%$ for II- $\boldsymbol{\beta}$. IR $\left(\mathrm{cm}^{-1}\right)$ for II- $\alpha$ : $3309 \mathrm{br}, 3131 \mathrm{~m}$, $1648 \mathrm{vs}, 1523 \mathrm{~m}, 1431 \mathrm{~m}, 1326 \mathrm{~m}, 1296 \mathrm{~s}, 1187 \mathrm{~m}, 967 \mathrm{w}$, $890 \mathrm{~m}, 813 \mathrm{~m}, 792 \mathrm{~m}, 626 \mathrm{w}$. IR $\left(\mathrm{cm}^{-1}\right)$ for II- $\beta$ : $3190 \mathrm{br}$, $3136 \mathrm{~m}, 3114 \mathrm{~m}, 1599 \mathrm{vs}, 1518 \mathrm{~m}, 1435 \mathrm{~m}, 1343 \mathrm{~s}, 1311 \mathrm{~s}$, $1195 \mathrm{w}, 969 \mathrm{~m}, 855 \mathrm{w}, 778 \mathrm{w}, 623 \mathrm{w}$.

\section{Preparation of $\left[\mathrm{Cu}(4-\mathrm{tza})_{2}\left(\mathrm{H}_{2} \mathrm{O}\right)_{2}\right]$ (III) and $[\mathrm{Cu}(4-$ tza) $)_{2} \cdot \mathbf{4} \mathrm{H}_{2} \mathrm{O}$ (IV)}

To obtain crystals of III, a solution of $\mathrm{Cu}\left(\mathrm{NO}_{3}\right)_{2} \cdot 2.5 \mathrm{H}_{2} \mathrm{O}$ $(0.0242 \mathrm{~g}, 0.100 \mathrm{mmol})$ in $8.0 \mathrm{~mL}$ of distilled water was slowly added to a solution of L-tryptophan $(0.0204 \mathrm{~g}$, $0.100 \mathrm{mmol}$ ) in 3:1 volumetric ratio of methanol and distilled water with constant stirring. To this mixture, a solution of 4-tza $(0.0129 \mathrm{~g}, 0.100 \mathrm{mmol})$ in $3.0 \mathrm{~mL}$ of ethanol was gently added with stirring. The mixture was then transferred to a Teflon bomb which was then placed in a water bath of approximate $1 \mathrm{~L}$ capacity. The reaction was carried out in a domestic microwave oven (Prestige SM23, medium high, $626 \mathrm{~W}$ ) for $30 \mathrm{~min}$. Anal. Calcd for $\left[\mathrm{Cu}(4-\mathrm{tza})_{2}\left(\mathrm{H}_{2} \mathrm{O}\right)_{2}\right]$ (III) (\%): C, 27.00; H, 2.27; N, 7.87; S, 18.02. Found (\%): C; 27.18; H, 1.94; N, 7.63; S, 17.89 . Yield based on $\mathrm{Cu}: 94 \%$. IR $\left(\mathrm{cm}^{-1}\right)$ for III: $3354 \mathrm{br}$, $3140 \mathrm{~m}, 3103 \mathrm{~m}, 1610 \mathrm{vs}, 1524 \mathrm{~m}, 1444 \mathrm{~s}, 1336 \mathrm{~m}, 1309 \mathrm{~s}$, $1195 \mathrm{w}, 972 \mathrm{~m}, 850 \mathrm{~m}, 779 \mathrm{~m}, 619 \mathrm{w}$.

Crystals of IV were obtained in similar way as described for III. However, $\mathrm{Cu}\left(\mathrm{NO}_{3}\right)_{2} \cdot 2.5 \mathrm{H}_{2} \mathrm{O}(0.0242 \mathrm{~g}, 0.100 \mathrm{mmol})$ 
was added to a solution of L-tryptophan (0.0204 g, $0.100 \mathrm{mmol}$ ) in 9:3 volumetric ratio of methanol and distilled water with constant stirring. To this mixture, a solution of 4-tza $(0.0129 \mathrm{~g}, 0.100 \mathrm{mmol})$ in $9.0 \mathrm{~mL}$ of ethanol was gently added with stirring. Anal. Calcd for $\left[\mathrm{Cu}(4-\mathrm{tza})_{2}\right] \cdot 4 \mathrm{H}_{2} \mathrm{O}(\mathrm{IV})$ (\%): C, 24.52; H, 3.09; N, 7.15; S, 16.37. Found (\%): C; 25.19; $\mathrm{H}, 2.62 ; \mathrm{N}, 7.15 ; \mathrm{S}, 18.19$. Yield based on $\mathrm{Cu}: 90 \%$. IR $\left(\mathrm{cm}^{-1}\right)$ for IV: $3236 \mathrm{br}, 3114 \mathrm{~m}, 3089 \mathrm{~m}, 1600 \mathrm{vs}, 1533 \mathrm{w}, 1432 \mathrm{~s}, 1347 \mathrm{~s}$, 1324w, 976w, 859w, 767w, 623w.

\section{Preparation of dehydrated compound of III and rehydrated compound of 'II'}

A crystalline sample of III was heated to $120{ }^{\circ} \mathrm{C}$ in a vial in an oven. Well-shaped crystals of a deep blue solid of III' were obtained after $1 \mathrm{~h}$ of heating. For the redydration process, a crystalline sample of III' $^{\prime}$ was placed in a closed double-vial system with saturated water vapour for a week.

\section{Temperature-controlled crystallization experiment for I and II}

In each experiment, an aqueous solution $(2.50 \mathrm{~mL})$ of $\mathrm{Co}\left(\mathrm{SO}_{4}\right) \cdot 7 \mathrm{H}_{2} \mathrm{O}\left(0.0281 \mathrm{~g}, 0.100 \mathrm{mmol}\right.$ ) (or $\mathrm{Ni}\left(\mathrm{SO}_{4}\right) \cdot 6 \mathrm{H}_{2} \mathrm{O}$ $(0.0296 \mathrm{~g}, 0.100 \mathrm{mmol}))$ was slowly added to an aqueous solution $(2.50 \mathrm{~mL})$ of 4 -Htza $(0.0129 \mathrm{~g}, 0.100 \mathrm{mmol})$ with constant stirring. The mixture was then left in oven at a constant temperature from room temperature to $80^{\circ} \mathrm{C}$. The orange crystals obtained in each experiment were isolated from mother liquor for analysis by X-ray diffraction.

\section{Solvent-controlled crystallization experiment for I}

Water, methanol and ethanol were used to explore the crystallization behaviour of $\mathbf{I}$. In a typical experiment, $\mathrm{Co}\left(\mathrm{SO}_{4}\right) \cdot 7 \mathrm{H}_{2} \mathrm{O}(0.0281 \mathrm{~g}, 0.100 \mathrm{mmol})$ was dissolved in $1.0 \mathrm{~mL}$ of distilled water and 4-Htza $(0.0129 \mathrm{~g}$, $0.100 \mathrm{mmol}$ ) was dissolved in $4.0 \mathrm{~mL}$ of water or a mixed solvent of 20,40, 60 and $80 \%$ of alcohol in water. The metal solution was slowly added to the ligand solution. The mixture was then left at room temperature. Orange crystals were obtained from the solution after several days through solvent evaporation. The crystals were isolated for analysis by X-ray diffraction.

\section{Crystal structure determination}

The sets of X-ray diffraction intensity data from I- $\boldsymbol{\beta}, \mathbf{I I}-\boldsymbol{\alpha}$, III and IV were collected in series of $\omega$-scans using a Stoe IPDS2 image plate diffractometer operating with Mo $K \alpha$ radiation at $150(2) K$ while the data set for II- $\boldsymbol{\beta}$ was collected in $\omega$-scans using a Bruker APEX-II CCD diffractometer operating with Mo $K \alpha$ radiation at 273(2) $K$. The collected data were corrected for absorption using the Tompa method in the case of large well-formed crystals [18]. In other cases, multi-scan absorption corrections were applied [19]. The structures were solved using dual-space methods within SHELXT and full-matrix least squares refinement was carried out within SHELXL-2014 via the WinGX program interface [20, 21]. All non-hydrogen positions were located in the direct and difference Fourier maps and refined using anisotropic displacement parameters. Hydrogen atoms attached to the tza were refined using a riding model. Hydrogen atoms of water were refined using a rigid body model for simplicity (I- $\boldsymbol{\beta}$ and III) but this approach led to unreasonably close approach of the water to adjacent tza in two cases (II- $\boldsymbol{\alpha}$ and IV) hence the hydrogen atoms were refined freely subject to sensible bond angle and distance restraints. Crystal structure data for the compounds reported here are summarized in Table 1. A preliminary check on the crystals of $\mathbf{I}-\boldsymbol{\alpha}$ revealed this to be isostructural with II- $\boldsymbol{\alpha}$. The sample of I- $\boldsymbol{\alpha}$ produced aggregates of crystals and we examined many crystallites, but did not find a crystal suitable for full data collection. Therefore, the full data set of $\mathbf{I}-\boldsymbol{\alpha}$ was, therefore, not collected, and a discussion is based on the data of II- $\boldsymbol{\alpha}$.

\section{Results and discussion}

The 4-tza ligand is found to act as a chelating ligand to ions of the first row of the transition series. However, the packing of the resulting coordination complexes leads to polymorphic forms in the solid state.

\section{Description of crystal structures}

$\left[\mathrm{Co}(4-\mathrm{tza})_{2}\left(\mathrm{H}_{2} \mathrm{O}\right)_{2}\right](\mathbf{I})$ and $\left[\mathrm{Ni}(4-\mathrm{tza})_{2}\left(\mathrm{H}_{2} \mathrm{O}\right)_{2}\right](\boldsymbol{I I})$

Two polymorphs of $\left[\mathrm{Co}(4-\mathrm{tza})_{2}\left(\mathrm{H}_{2} \mathrm{O}\right)_{2}\right]$ (I), hereafter referred to as $\mathbf{I}-\boldsymbol{\alpha}$ and $\mathbf{I}-\boldsymbol{\beta}$ have been identified. Crystallographic data reveal that these polymorphs are isostructural with those of $\left[\mathrm{Ni}(4-\mathrm{tza})_{2}\left(\mathrm{H}_{2} \mathrm{O}\right)_{2}\right]$ (II) and, therefore, the description of the crystal structures will be based on those of II in the following section.

\section{Molecular structure of II}

The molecular structure of the discrete complex [Ni(4-tza) $\left.\left(\mathrm{H}_{2} \mathrm{O}\right)_{2}\right]$ (II) found in each polymorph $(\boldsymbol{\alpha}$ and $\boldsymbol{\beta})$ is illustrated below in Fig. 1. The nickel(II) cation is hexacoordinated with two ligands of 4-tza occupying the equatorial plane displaying $\kappa^{2}-\mathrm{N}, \mathrm{O}$ coordination mode producing chelating five membered rings. The two remaining axial coordination sites are occupied by two water ligands directly bonding to the metal centre which lies on the 
Table 1 Crystallographic data of I, II, III and IV

\begin{tabular}{|c|c|c|c|c|c|c|c|}
\hline \multirow[t]{2}{*}{ Compound name } & \multicolumn{2}{|c|}{$\left[\mathrm{Co}(4-\mathrm{tza})_{2}\left(\mathrm{H}_{2} \mathrm{O}\right)_{2}\right](\mathbf{I})$} & \multicolumn{2}{|c|}{$\left[\mathrm{Ni}(4-\mathrm{tza})_{2}\left(\mathrm{H}_{2} \mathrm{O}\right)_{2}\right](\mathbf{I I})$} & \multirow{2}{*}{$\begin{array}{l}{\left[\mathrm{Cu}(4-\mathrm{tza})_{2}\left(\mathrm{H}_{2} \mathrm{O}\right)_{2}\right]} \\
(\mathrm{III})\end{array}$} & \multirow{2}{*}{$\begin{array}{l}{\left[\mathrm{Cu}(4-\mathrm{tza})_{2}\right] \cdot 4 \mathrm{H}_{2} \mathrm{O}} \\
(\mathrm{IV})\end{array}$} & \multirow{2}{*}{$\begin{array}{l}{\left[\mathrm{Cu}(4-\mathrm{tza})_{2}\right]^{\mathrm{a}}} \\
{[17]}\end{array}$} \\
\hline & $\alpha$ & $\beta$ & $\alpha$ & $\beta$ & & & \\
\hline Formula weight & & 351.21 & 350.99 & 350.99 & 355.82 & 391.86 & 319.79 \\
\hline Colour & Orange & Orange & Light blue & Blue & Green & Blue & Deep blue \\
\hline Crystal system & Monoclinic & Monoclinic & Monoclinic & Monoclinic & Monoclinic & Monoclinic & Monoclinic \\
\hline Space group & $P 2_{1} / \mathrm{n}$ & $P 2_{1} / \mathrm{c}$ & $P 2_{1} / \mathrm{n}$ & $P 2_{1} / \mathrm{c}$ & $P 2_{1} / \mathrm{c}$ & $P 2_{1} / \mathrm{c}$ & $P 2_{1} / \mathrm{c}$ \\
\hline Temperature (K) & $150(2)$ & $150(2)$ & $150(2)$ & $273(2)$ & $150(2)$ & $150(2)$ & $293(2)$ \\
\hline Wavelength $(\AA)$ & 0.71073 & 0.71073 & 0.71073 & 0.71073 & 0.71073 & 0.71073 & 0.71073 \\
\hline$a(\AA)$ & $5.281(3)$ & $5.2099(6)$ & $5.2956(6)$ & $5.2437(2)$ & $5.3948(6)$ & $9.892(5)$ & $5.211(5)$ \\
\hline$b(\AA)$ & $5.294(3)$ & $11.3765(10)$ & $5.2895(3)$ & $11.2405(4)$ & $11.2130(13)$ & $7.606(3)$ & $11.634(3)$ \\
\hline$c(\AA)$ & $21.342(11)$ & $9.8322(10)$ & $21.046(2)$ & $9.8395(4)$ & $9.7694(12)$ & $9.108(4)$ & $8.136(2)$ \\
\hline$\beta\left(^{\circ}\right)$ & $97.040(5)$ & $99.344(9)$ & $97.291(9)$ & $98.6390(10)$ & $97.389(10)$ & $95.84(4)$ & $91.52(5)$ \\
\hline$V\left(\AA^{3}\right)$ & $583.29(4)$ & $575.03(10)$ & $584.75(9)$ & $573.38(4)$ & $586.06(12)$ & $681.8(5)$ & $493.1(5)$ \\
\hline$Z$ & & 2 & 2 & 2 & 2 & 2 & \\
\hline$D_{\text {calc }}\left(\mathrm{g} \mathrm{cm}^{-3}\right)$ & & 2.028 & 1.993 & 2.033 & 2.016 & 1.909 & \\
\hline $\begin{array}{l}\text { Absorption coefficient } \\
\left(\mathrm{mm}^{-1}\right)\end{array}$ & & 1.880 & 2.040 & 2.081 & 2.244 & 1.949 & \\
\hline $\begin{array}{l}\theta \text { range for data } \\
\text { collection }\left(^{\circ}\right)\end{array}$ & & $2.10-29.55$ & $1.95-26.20$ & $3.63-28.21$ & $2.80-29.65$ & $2.05-29.55$ & \\
\hline$F(000)$ & & 354 & 356 & 356 & 358 & 398 & \\
\hline $\begin{array}{l}\text { Data/ } \\
\text { restraints/parameters }\end{array}$ & & $1535 / 3 / 92$ & $2726 / 4 / 95$ & $1416 / 3 / 92$ & $1573 / 0 / 89$ & $1834 / 6 / 114$ & \\
\hline Goodness-of-fit on $F^{2}$ & & 0.961 & 1.164 & 1.051 & 0.959 & 0.979 & \\
\hline $\mathrm{R} 1, \mathrm{wR} 2[I>2 \theta(\mathrm{I})]$ & & $\begin{array}{c}0.0243 \\
0.0604\end{array}$ & $\begin{array}{r}0.1038 \\
0.2565\end{array}$ & $\begin{array}{c}0.0229 \\
0.0507\end{array}$ & $0.0340,0.0647$ & $0.0286,0.0716$ & \\
\hline
\end{tabular}

${ }^{\mathrm{a}}\left[\mathrm{Cu}(4-\mathrm{tza})_{2}\right]$ unit cell was determined from powder data and agrees with that in reference [17]

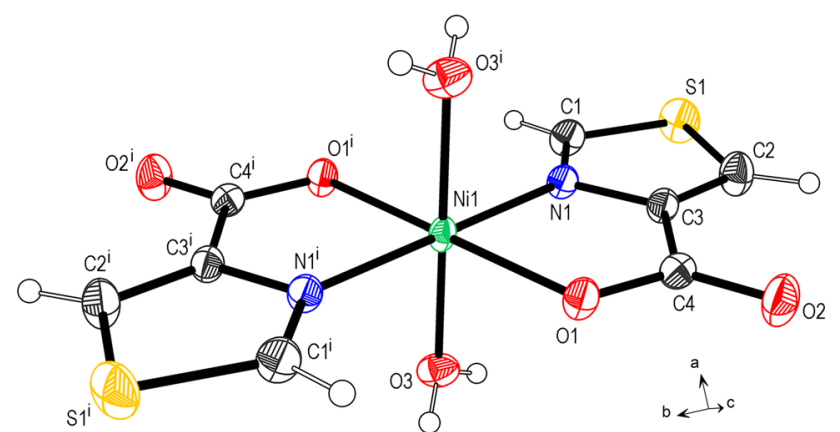

Fig. 1 Molecular structure of $\left[\mathrm{Ni}(4-\mathrm{tza})_{2}\left(\mathrm{H}_{2} \mathrm{O}\right)_{2}\right]$ in $\mathbf{I I -} \boldsymbol{\alpha}$ and II- $\boldsymbol{\beta}$ polymorphs drawn at $50 \%$ probability ellipsoids with non-hydrogen atom labeling scheme. Symmetry code: (i) $-\mathrm{x}+1,-\mathrm{y}+1,-\mathrm{z}+1$

crystallographic inversion centre. The coordination geometry for II can be described as a roughly regular octahedral geometry in which the $\mathrm{Ni}-\mathrm{N}$ and $\mathrm{Ni}-\mathrm{O}$ distances are not significantly different from each other, ranging from $2.023(10)$ to $2.092(10) \AA$ (for $\mathbf{I I}-\boldsymbol{\alpha}$ form) and from $2.0322(13)$ to 2.0925 (13) $\AA$ (for II- $\boldsymbol{\beta}$ form) and the axial $\mathrm{O} 3-\mathrm{Ni} 1-\mathrm{O} 3 \mathrm{i}$ is almost perpendicular to the coordination square-plane of the nickel(II) ion found in both polymorphs. It is possible to examine the difference in orientation of the ligands by overlaying the molecules of $\mathbf{I I}-\boldsymbol{\alpha}$ and $\mathbf{I I}-\boldsymbol{\beta}$ polymorphs. The differences are strikingly small; there appears to be a small change in the location and orientation of the water ligand (Fig. 2) but the hydrogen-bonding interactions formed by this water appear very similar. It is, therefore, the different packing of these units that leads to different polymorphs.

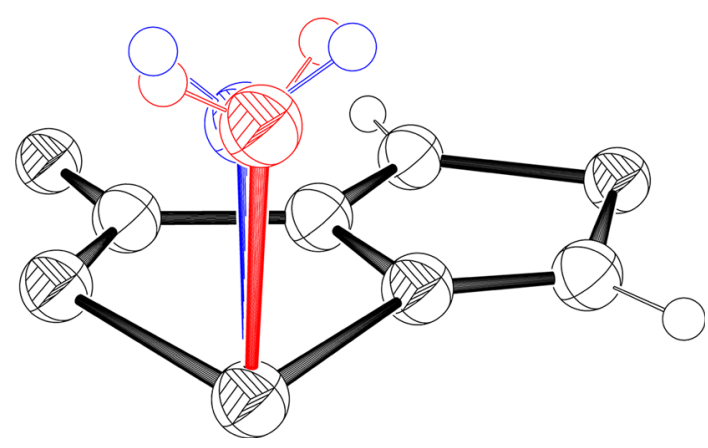

Fig. 2 View of overlaying asymmetric units of II- $\boldsymbol{\alpha}$ (blue) and II- $\boldsymbol{\beta}$ (red) polymorphs. (Color figure online) 


\section{Molecular packing of $\mathbf{I I - \alpha}$ and $\mathbf{I I - \beta}$ polymorphs}

The differences in the molecular packings of II- $\boldsymbol{\alpha}$ and II- $\boldsymbol{\beta}$ polymorphs are remarkable, as shown in Fig. 3. II- $\alpha$ form crystallizes in monoclinic cell with space group $P{ }_{1} / n$. Two $\mathrm{O}-\mathrm{H} \cdots \mathrm{O}$ hydrogen bonds between the coordinating water ligands and the carboxylate oxygen atoms and a $\mathrm{C}-\mathrm{H} \cdots \mathrm{O}$ weak hydrogen bonding interaction between the thiazole ring and the adjacent carboxylate oxygen atom bring the mononuclear species into a layered structure, as shown in Fig. 4a, b and listed in Table 2. If the [Ni(4-tza $\left.)_{2}\left(\mathrm{H}_{2} \mathrm{O}\right)_{2}\right]$ unit of II- $\boldsymbol{\alpha}$ is taken as a node, the hydrogen bonding network can be simplified as a two-dimensional 6-connected uninodal hxl/Shubnikov $(3,6)$ plane net with Schläfli symbol $3^{6} \cdot 4^{6} \cdot 5^{3}$ (Fig. 4c) [22]. These layers are further connected by inter-plane thiazole-carbonyl interactions and packed along the $c$-axis in ABAB stacking fashion (Fig. 5). Considering the inter-plane $\mathrm{S} \cdots \mathrm{O}$ contact with the non-

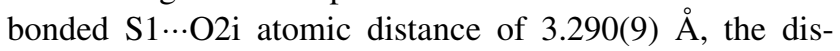
tance which is significantly less than the sum of the van der Waals radii of $\mathrm{S}$ and $\mathrm{O}$ atoms ( $3.35 \AA$ ) indicates a possible interaction of $\mathrm{S} 1$ and $\mathrm{O} 2$ atoms with an $\mathrm{S} 1 \cdots \mathrm{O} 2=\mathrm{C}$ bond angle of $130.8(8)^{\circ}$ resulting in the formation of the threedimensional supramolecular network [23, 24]. This nonbonded S $\cdots \mathrm{O}$ interaction is only observed in II- $\alpha$ possibly causing a less close-packed structure and a longer c-axis compared to II- $\boldsymbol{\beta}$ (Table 1).

The polymorph II- $\boldsymbol{\beta}$ crystallizes in a different unit cell from II- $\alpha$; each is monoclinic but these are different setting of the same space group of $P 2_{1} / c$. It is important to note that although each polymorph crystallizes in space group 14 , the relationship between them is not a trivial resetting of the axes. The hydrogen bonding interactions found in II- $\boldsymbol{\beta}$ form are significantly different from that of II- $\boldsymbol{\alpha}$ form. The discrete $\left[\mathrm{Ni}(4-\mathrm{tza})_{2}\left(\mathrm{H}_{2} \mathrm{O}\right)_{2}\right]$ units of $\mathbf{I I -} \boldsymbol{\beta}$ are held together through intramolecular hydrogen bonding interactions to form a three-dimensional network structure, as illustrated in Fig. 4d, e and listed in Table 2. Each coordinating water ligand acts as both hydrogen bonding donor and acceptor involved in three hydrogen bonding interactions; two strong $\mathrm{O}-\mathrm{H} \cdots \mathrm{O}$ hydrogen bonds with the carboxylate oxygen atoms of adjacent mononuclear molecules and one weak $\mathrm{C}-\mathrm{H} \cdots \mathrm{O}$ hydrogen bonding interaction involving the thiazole ring. A weak $\mathrm{C}-\mathrm{H} \cdots \mathrm{O}$ hydrogen bonding interaction between the thiazole ring and uncoordinated carboxyl oxygen atom is also observed. If the $\left[\mathrm{Ni}(4-\mathrm{tza})_{2}\left(\mathrm{H}_{2} \mathrm{O}\right)_{2}\right]$ is taken as a node, then the hydrogen bonding network in II- $\boldsymbol{\beta}$ polymorph can be simplified to a three-dimensional 10-connected uninodal bct net with Schläfli symbol $3^{12} \cdot 4^{28} \cdot 5^{5}$ (Fig. 4f) [22].

$\left[\mathrm{Cu}(4-\mathrm{tza})_{2}\left(\mathrm{H}_{2} \mathrm{O}\right)_{2}\right]($ III $)$

Complex III crystallizes in monoclinic cell with space group $P 2{ }_{1} / c$. The molecular structure of III is almost identical to that of $\mathbf{I}-\boldsymbol{\beta}$ and $\mathbf{I I}-\boldsymbol{\beta}$ polymorphs where the copper(II) cation is bonded to two 4-tza ligands in trans positions with five-membered chelate rings in the equatorial plane and two aqua ligands in the axial positions, in which the crystallographic inversion centre is located at the copper centre. Compared with those two structures, the $\mathrm{Cu}-\mathrm{OH}_{2}$ bond length of 2.3759(16) $\AA$ found in III is significantly longer that of $\mathrm{Co}-\mathrm{OH}_{2}(2.1054(12) \AA)$ and $\mathrm{Ni}-$ $\mathrm{OH}_{2}(2.0925(13) \AA)$ found in $\mathbf{I}-\boldsymbol{\beta}$ and II- $\boldsymbol{\beta}$ polymorphs, respectively. This can be explained by a Jahn-Teller effect of the copper(II) ion resulting in an elongated octahedral geometry for the copper centre. This difference in coordination geometry of the metal centre does not affect the hydrogen bonding interactions among these isostructures. The hydrogen bonds found in III are similar to that of I- $\boldsymbol{\beta}$ and II- $\boldsymbol{\beta}$ polymorphs (Table 2 ) giving rise to the same three-dimensional hydrogen bonding net topology of 10-connected uninodal bet net with Schläfli symbol $3^{12} \cdot 4^{28} \cdot 5^{5}[22]$.

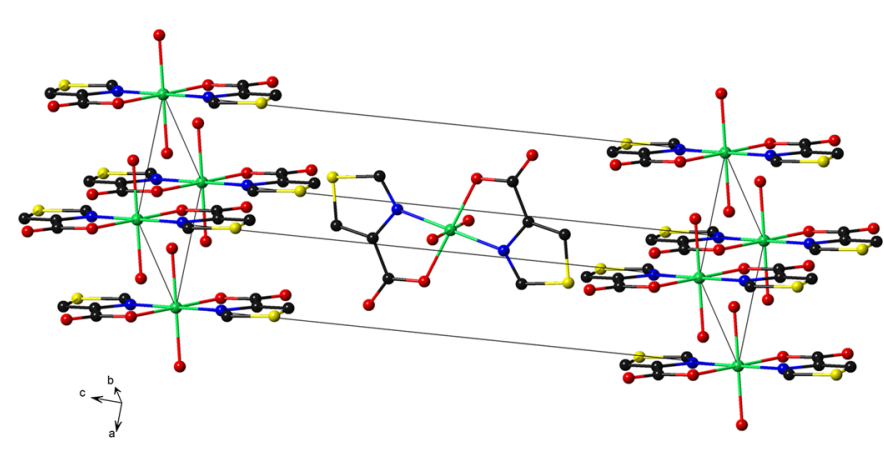

II- $\alpha$ polymorph

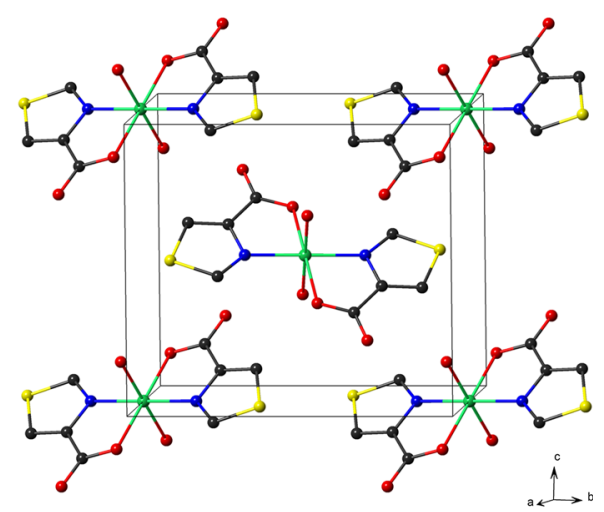

$\|$ - $\beta$ polymorph

Fig. 3 Diagram showing the molecular packing of polymorphs in II 
Fig. 4 Views of hydrogen bonding interactions in (a) $\mathbf{I I}-\boldsymbol{\alpha}$ and (d) II- $\boldsymbol{\beta}$. Diagrams depicting hydrogen bonding frameworks in (b) II- $\alpha$ with 6-connected uninodal hxl/ Shubnikov $(3,6)$ plane net (c) and in (e) II- $\boldsymbol{\beta}$ with 10-connected uninodal bet net (f)

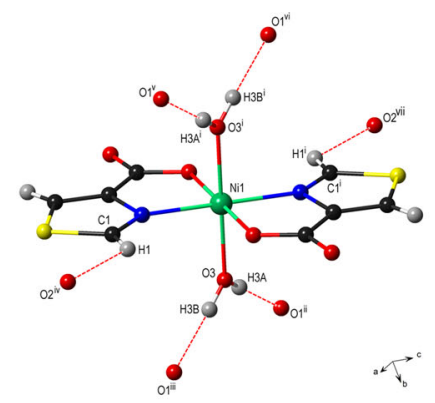

(a)

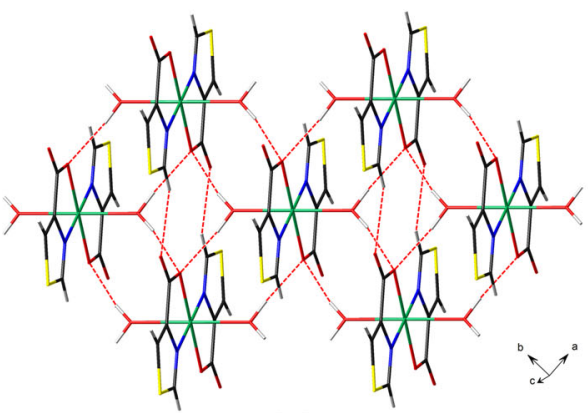

(b)

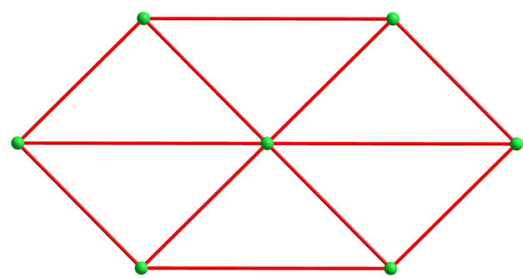

(c)

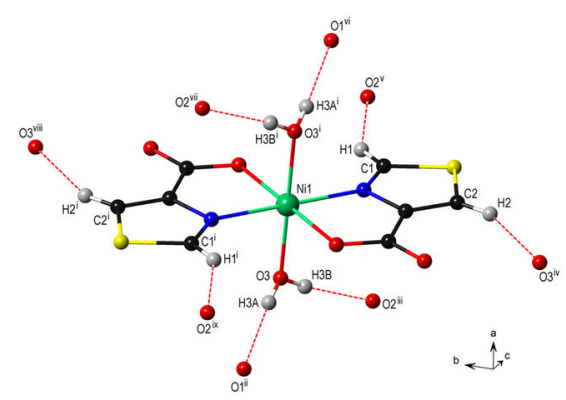

(d)

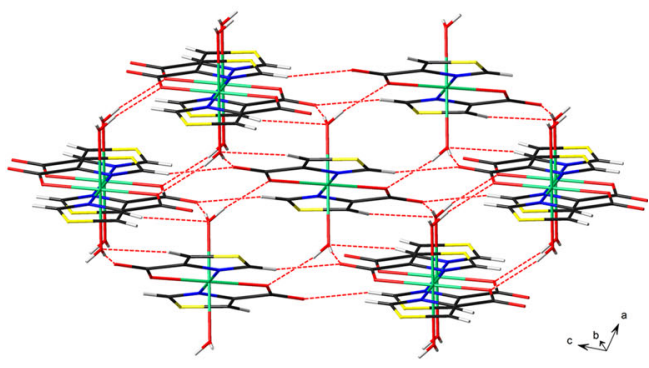

(e)

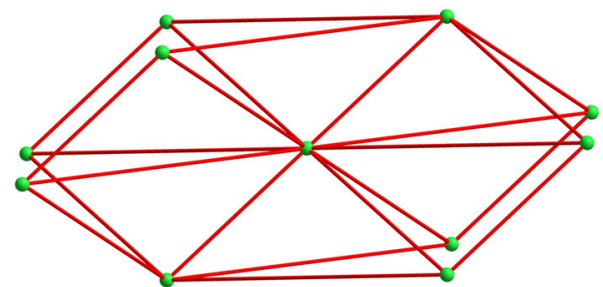

(f)
$\left[\mathrm{Cu}(4-\mathrm{tza})_{2}\right] \cdot 4 \mathrm{H}_{2} \mathrm{O}(\mathrm{IV})$

Complex IV crystallizes in the same crystal system and space group as III. However, the asymmetric unit consists of one copper(II) cation which is located on an inversion centre and is $\mathrm{N}, \mathrm{O}$-chelated by two 4-tza ligands in the equatorial plane and further coordinated by two bridging carboxylate $\mathrm{O}$ atoms from another two 4-tza ligands in the axial positions, with an elongated octahedral geometry with the $\mathrm{Cu}-\mathrm{O}$ bond length of 2.6857(19) $\AA$ and two lattice water molecules (Fig. 6). The 4-tza ligand in IV is found to act as chelating and bridging to the copper(II) ions. Therefore, instead of forming a discrete molecule like III, a two-dimensional layer with 4-connected uninodal sql/Shubnikov tetragonal plane net (Schläfli symbol $4^{4} \cdot 6^{2}$ ) is found [22], as depicted in Fig. $7 \mathrm{a}, \mathrm{b}$ and each layer is held together by strong hydrogen bonding interactions between carboxyl $\mathrm{O} 3$ atoms and lattice water molecules and between lattice water molecules themselves (Table 2).
Thermal properties of the complexes of II

Thermogravimetric analysis (TGA) reveals that $\mathbf{I I}-\boldsymbol{\alpha}$ and II- $\boldsymbol{\beta}$ polymorphs possess high thermal stability up to 180 and $215{ }^{\circ} \mathrm{C}$, respectively (Fig. 8a). On heating from room temperature to $900{ }^{\circ} \mathrm{C}$, two major weight losses were observed. The first weight loss of approximately $12.35 \%$ (calc. $10.26 \%$ ) occurring in a temperature range of $180-280{ }^{\circ} \mathrm{C}$ is related to the loss of two coordinating water ligands. At approximately $300{ }^{\circ} \mathrm{C}$, the second weight loss of $66.58 \%$ began which corresponds to the decomposition of the organic ligands (calc. $73.58 \%$ ). At the end of analysis, $21.07 \%$ of ash remained. There are notable differences in the TGA traces here; II- $\boldsymbol{\beta}$ retains water to a higher temperature (loss begins around $215{ }^{\circ} \mathrm{C}$ ) but II- $\alpha$ appears to convert to a phase that is moderately stable between 250 and $300{ }^{\circ} \mathrm{C}$. As expected the decomposition of the two phases yields the same final product. The DSC trace (Fig. 8b) is featureless around $50-60{ }^{\circ} \mathrm{C}$ where the II- $\boldsymbol{\beta}$ polymorph might be expected to form. This confirms 
Table 2 Lists of hydrogen bonding interactions in the complexes

\begin{tabular}{|c|c|c|c|}
\hline D-H $\cdots A$ & $\mathrm{H} \cdots \mathrm{A}(\AA)$ & $\mathrm{D} \cdots \mathrm{A}(\AA)$ & $\angle \mathrm{D}-\mathrm{H} \cdots \mathrm{A}\left({ }^{\circ}\right)$ \\
\hline \multicolumn{4}{|l|}{ I- $\boldsymbol{\beta}$ polymorph } \\
\hline $\mathrm{O} 3-\mathrm{H} 3 \mathrm{~A} \cdots \mathrm{O} 2^{\mathrm{i}}$ & 1.99 & $2.7878(17)$ & 173 \\
\hline $\mathrm{O} 3-\mathrm{H} 3 \mathrm{~B} \cdots \mathrm{O} 1^{\mathrm{ii}}$ & 1.95 & $2.7632(16)$ & 172 \\
\hline $\mathrm{C} 1-\mathrm{H} 1 \cdots \mathrm{O} 2^{\mathrm{iii}}$ & 2.34 & $3.153(2)$ & 143 \\
\hline $\mathrm{C} 2-\mathrm{H} 2 \cdots \mathrm{O} 3^{\mathrm{iv}}$ & 2.38 & $3.253(2)$ & 152 \\
\hline \multicolumn{4}{|l|}{ II $\boldsymbol{\alpha}$ polymorph } \\
\hline $\mathrm{O} 3-\mathrm{H} 3 \mathrm{~A} \cdots \mathrm{O} 1^{\mathrm{v}}$ & 1.91 & $2.7527(3)$ & 168 \\
\hline $\mathrm{O} 3-\mathrm{H} 3 \mathrm{~B} \cdots \mathrm{O} 1^{\mathrm{vi}}$ & 1.94 & $2.7887(3)$ & 171 \\
\hline $\mathrm{C} 1-\mathrm{H} 1 \cdots \mathrm{O} 2^{\mathrm{vii}}$ & 2.46 & $3.0375(3)$ & 120 \\
\hline \multicolumn{4}{|l|}{ II- $\boldsymbol{\beta}$ polymorph } \\
\hline $\mathrm{O} 3-\mathrm{H} 3 \mathrm{~A} \cdots \mathrm{O} 1^{\mathrm{viii}}$ & 2.06 & $2.7872(1)$ & 171 \\
\hline $\mathrm{O} 3-\mathrm{H} 3 \mathrm{~B} \cdots \mathrm{O} 2^{\mathrm{ix}}$ & 2.04 & $2.7976(1)$ & 174 \\
\hline $\mathrm{C} 1-\mathrm{H} 1 \cdots \mathrm{O} 2^{\mathrm{x}}$ & 2.38 & $3.1585(1)$ & 141 \\
\hline $\mathrm{C} 2-\mathrm{H} 2 \cdots \mathrm{O} 3^{\mathrm{xi}}$ & 2.41 & $3.2580(1)$ & 152 \\
\hline \multicolumn{4}{|l|}{ III } \\
\hline $\mathrm{O} 3-\mathrm{H} 3 \mathrm{~A} \cdots \mathrm{O} 1^{\mathrm{xii}}$ & 1.96 & $2.8322(19)$ & 178 \\
\hline $\mathrm{O} 3-\mathrm{H} 3 \mathrm{~B} \cdots \mathrm{O} 2^{\mathrm{xiii}}$ & 1.94 & $2.808(2)$ & 172 \\
\hline $\mathrm{C} 1-\mathrm{H} 1 \cdots \mathrm{O} 2^{\mathrm{iii}}$ & 2.42 & $3.170(2)$ & 136 \\
\hline $\mathrm{C} 2-\mathrm{H} 2 \cdots \mathrm{O} 3^{\mathrm{xiv}}$ & 2.35 & $3.205(2)$ & 149 \\
\hline \multicolumn{4}{|l|}{ IV } \\
\hline $\mathrm{O} 3-\mathrm{H} 3 \mathrm{~A} \cdots \mathrm{O} 2^{\mathrm{v}}$ & 1.88 & $2.636(2)$ & 176 \\
\hline $\mathrm{O} 3-\mathrm{H} 3 \mathrm{~B} \cdots \mathrm{O} 4^{\mathrm{v}}$ & 1.90 & $2.653(2)$ & 164 \\
\hline $\mathrm{O} 4-\mathrm{H} 4 \mathrm{~A} \cdots \mathrm{O}^{\mathrm{xv}}$ & 2.25 & $3.021(3)$ & 167 \\
\hline $\mathrm{O} 4-\mathrm{H} 4 \mathrm{~B} \cdots \mathrm{O}^{\mathrm{xvi}}$ & 2.10 & $2.860(3)$ & 171 \\
\hline $\mathrm{C} 1-\mathrm{H} 1 \cdots \mathrm{O} 4^{\mathrm{xvii}}$ & 2.39 & $3.207(3)$ & 143 \\
\hline $\mathrm{C} 2-\mathrm{H} 2 \cdots \mathrm{O} 1^{\mathrm{i}}$ & 2.48 & $3.308(3)$ & 146 \\
\hline
\end{tabular}

that there is no interconversion from II- $\boldsymbol{\alpha}$ to II- $\boldsymbol{\beta}$ upon thermal annealing.

\section{Temperature-controlled crystallization and polymorphic formation of I and II}

The crystal packing can be controlled by the temperature of the solution from which the crystals are grown, and the stable nature of the two polymorphs does not allow interconversion between the two different crystal structures once formed. We have been unable to interconvert the two forms by annealing with and without solvent present. However, it is possible to control the formation of the different polymorphs by controlling the reaction conditions.

The effect of crystallization temperature on crystal growth behaviour and polymorphic formation of I and II was investigated. The overlay of the experimental powder diffraction patterns with the calculated one (Fig. 9a, b) shows good correlation of the crystal structures with the

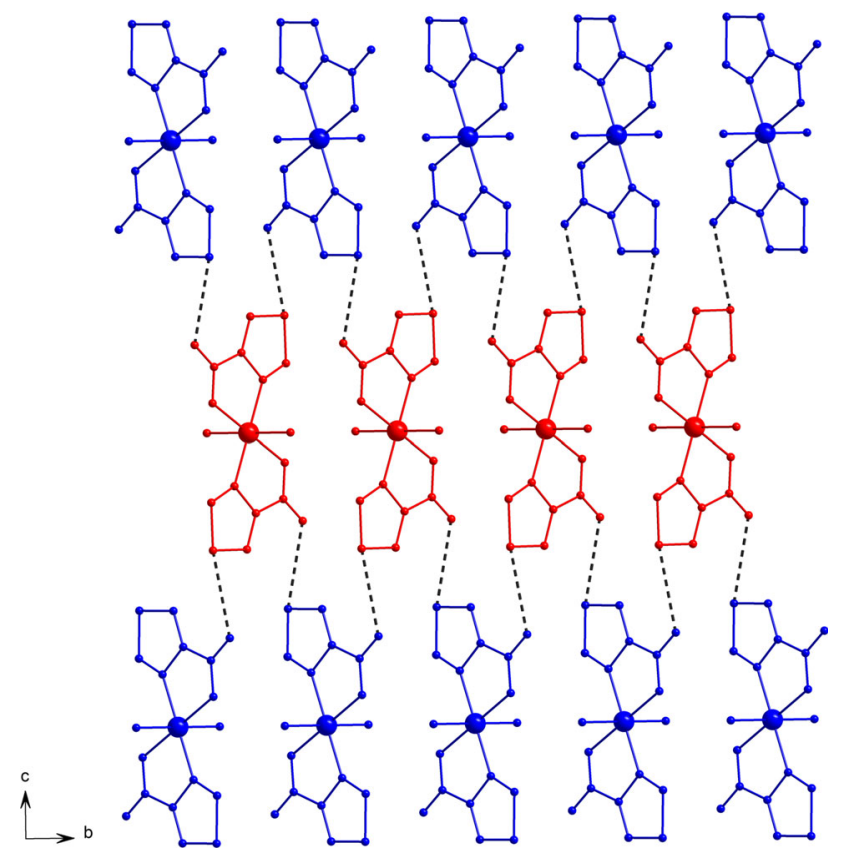

Fig. 5 View of non-bonded S...O interactions (dash lines) between two adjacent planes in II- $\alpha$

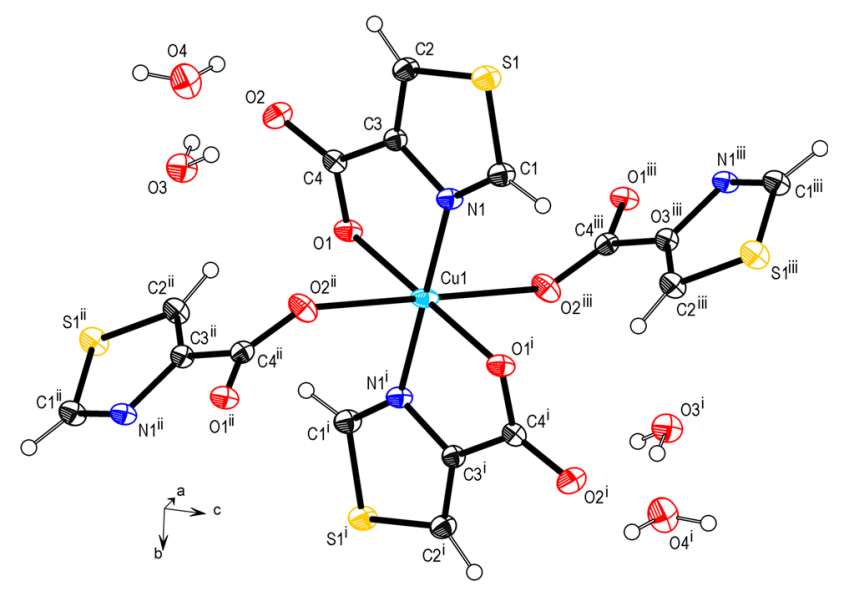

Fig. 6 Molecular structure of IV drawn at $50 \%$ probability ellipsoids with non-hydrogen atom labeling scheme. Symmetry code: (i) $-\mathrm{x}+1,-\mathrm{y}+2,-\mathrm{z}+1$; (ii) $-\mathrm{x}+1, \mathrm{y}+1 / 2,-\mathrm{z}+1 / 2$; (iii) $\mathrm{x}$, $-\mathrm{y}+3 / 2, \mathrm{z}+1 / 2$

bulk material, indicating the purity of the bulk phase in each case.

It is obvious from the PXRD patterns that crystallization temperature does not have an effect on the formation of polymorphs in $\mathbf{I}$. At any studied temperature conditions, only I- $\boldsymbol{\beta}$ polymorph was obtained (Fig. 9a). Interestingly, in the case of II, we observe that when the crystallization occurs at near room temperature, only II- $\alpha$ polymorph is obtained. The temperature between 50 and $60{ }^{\circ} \mathrm{C}$ is a transition state in which a mixture of II- $\boldsymbol{\alpha}$ and II- $\boldsymbol{\beta}$ 
Fig. 7 a View of the twodimensional framework in IV and $\mathbf{b}$ diagram depicting 4-connected uninodal sql/ Shubnikov tetragonal plane net

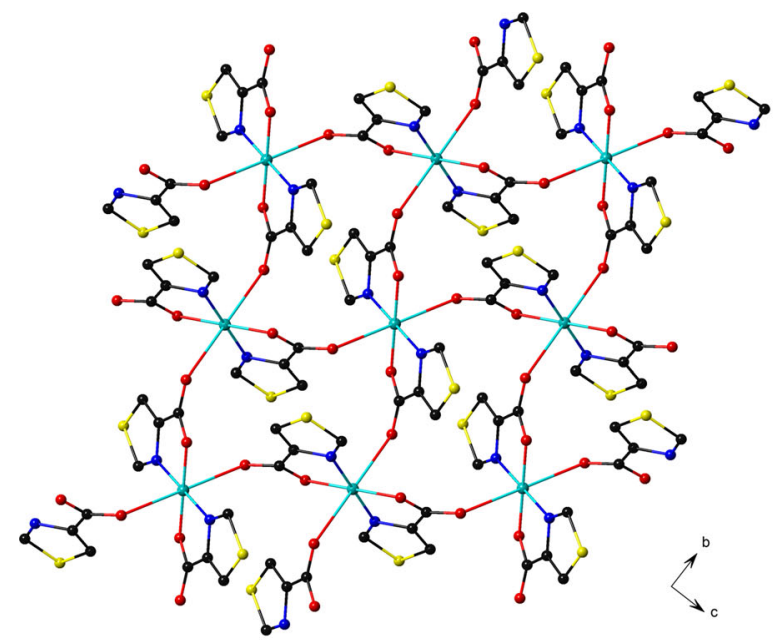

(a)

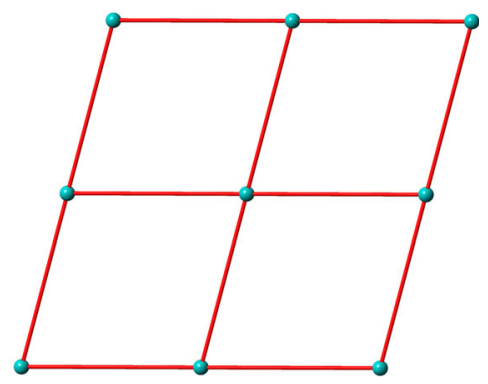

(b)

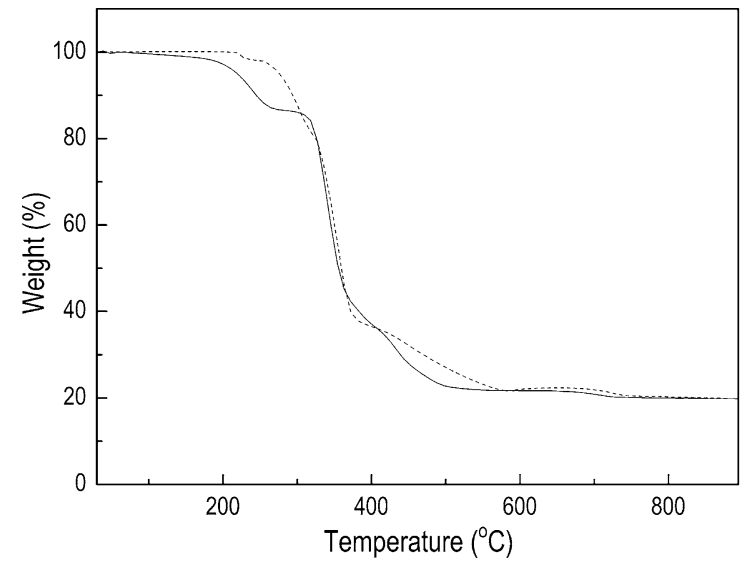

(a)

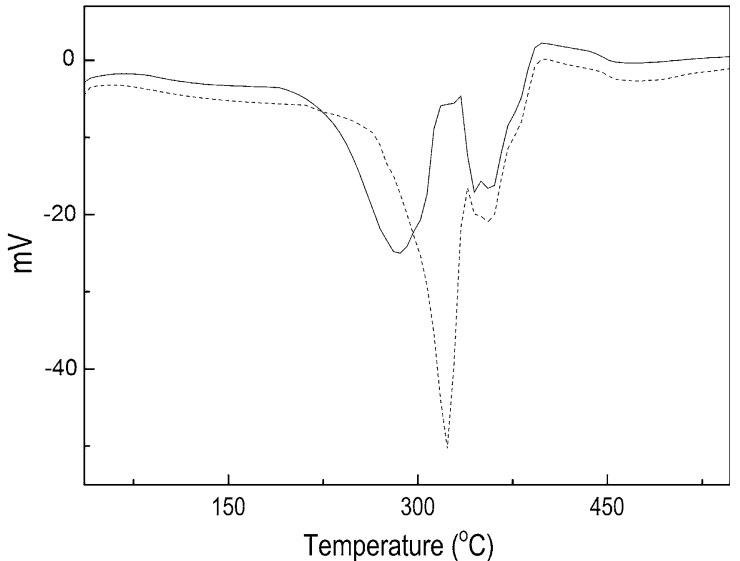

(b)

Fig. 8 a TGA and b DSC curves for II- $\boldsymbol{\alpha}$ (solid line) and II- $\boldsymbol{\beta}$ (dash line) polymorphs

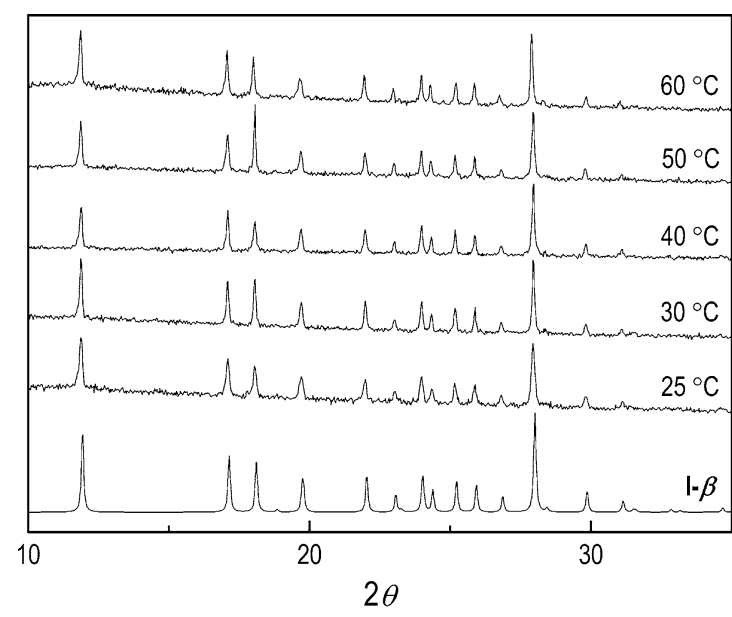

(a)

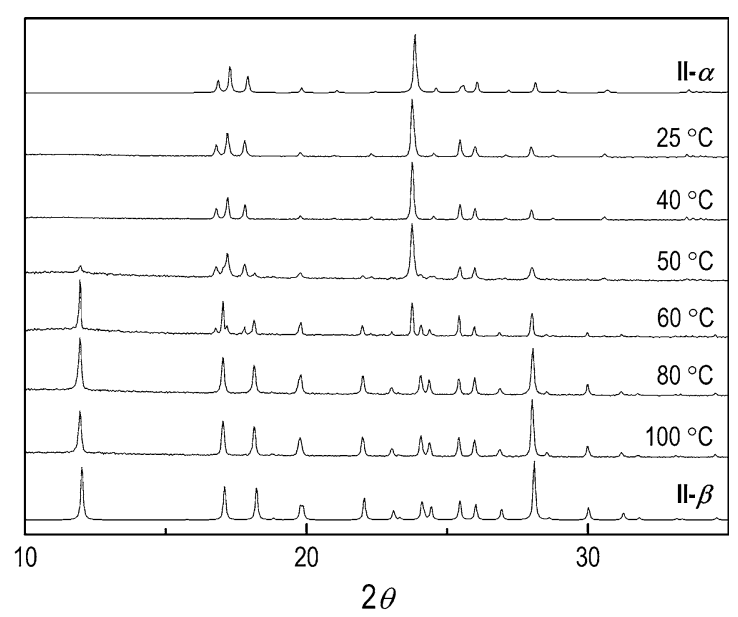

(b)

Fig. 9 PXRD patterns showing the study of temperature-controlled crystallization of I (a) and II (b) 


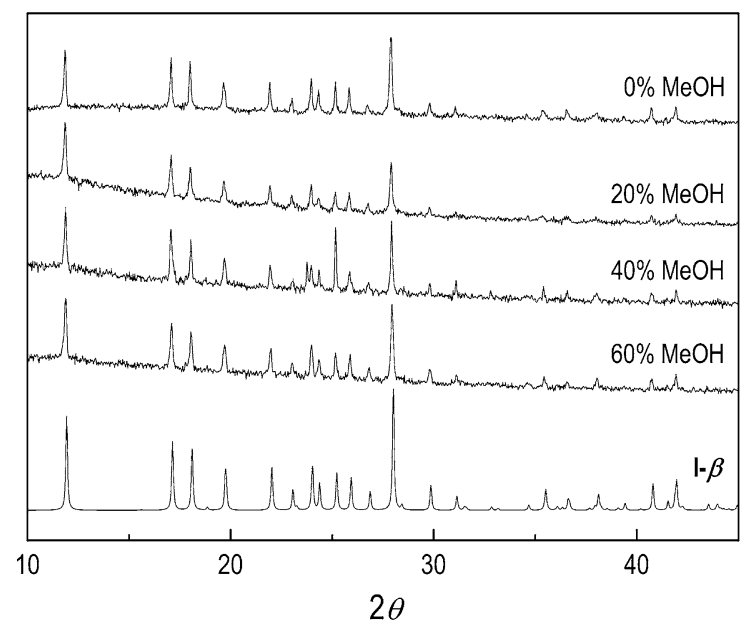

(a)

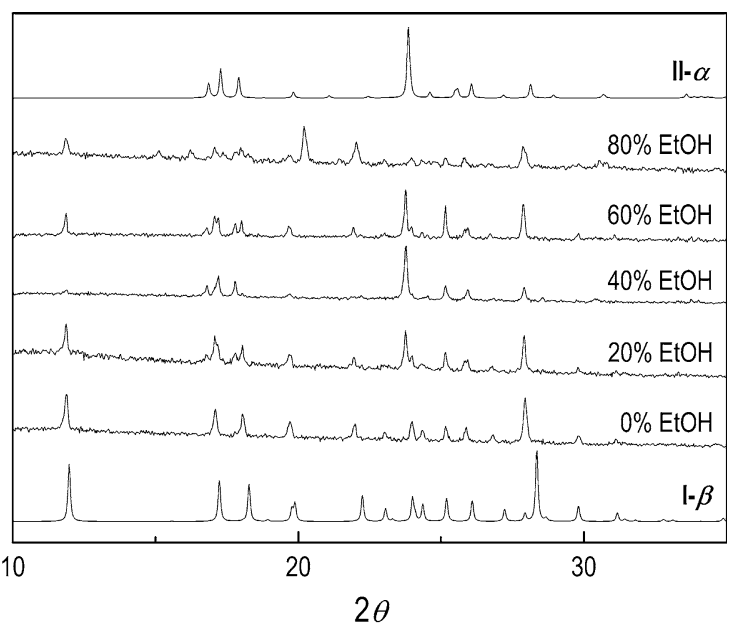

(b)

Fig. 10 X-ray powder diffraction patterns showing crystallization behaviour of $\mathbf{I}$ in a mixed solvent of methanol with water (a) and ethanol with water (b)

polymorphs can be observed. When the temperature is raised to and over $80{ }^{\circ} \mathrm{C}$, only $\mathbf{I I} \boldsymbol{\beta} \boldsymbol{\beta}$ polymorph is formed (Fig. 9b). It can be noted that the temperature plays a key role in determining type of the derived polymorphs in II. II- $\boldsymbol{\alpha}$ and $\mathbf{I I}-\boldsymbol{\beta}$ polymorphs can be, therefore, synthesized in bulk quantities through a temperature-control strategy.

\section{Solvent-controlled crystallization and polymorphic formation of I}

Water, methanol and ethanol were used to explore the crystallization behaviour of $\mathbf{I}$. The solvent affects the crystal growth and the formation of polymorphs in $\mathbf{I}$ as seen by Fig. $10 a$, b. I- $\boldsymbol{\beta}$ polymorph can be readily obtained in the bulk in a wide range of solvents, e.g. water and mixed solvents of 20,40 and $60 \%$ methanol in water (Fig. 10a) at room temperature. In addition, I- $\boldsymbol{\beta}$ polymorph can be formed quickly from an aqueous solution at $80^{\circ} \mathrm{C}$. In contrast, $\mathbf{I}-\boldsymbol{\alpha}$ polymorph can only be obtained from a mixed solvent of $40 \%$ ethanol with water (Fig. 10b). Furthermore, when using 20 and $60 \%$ of ethanol in water as solvents, a mixture of $\mathbf{I}-\boldsymbol{\alpha}$ and $\mathbf{I}-\boldsymbol{\beta}$ polymorphs can be observed. By using $80 \%$ of ethanol in water, a poorly crystalline unknown phase which is not corresponding to either $\mathbf{I}-\boldsymbol{\alpha}$ nor $\mathbf{I}-\boldsymbol{\beta}$ phases is observed. These results indicate a solvent-selective crystallization process of $\mathbf{I}$. It can be concluded that $\mathbf{I}-\boldsymbol{\alpha}$ and $\mathbf{I}-\boldsymbol{\beta}$ polymorphs can be synthesized in bulk quantities through a solvent-control strategy. The fact that seemingly small changes in solvent composition lead to different polymorphs is unexpected. Presumably during crystallization, interactions between the solvent and metal complexes are crucial in determining the packing present.

\section{Solvent-dependent crystallization of III and IV}

The microwave-assisted solvothermal technique has proved to be an effective way to obtain crystals of suitable quality for single crystal X-ray diffraction experiments. The syntheses of III with and without L-tryptophan were investigated. Strangely, it was found that III can only be obtained in the presence of L-tryptophan although this was not present in the product. We do not understand the role of this additive in the synthesis.

An attempt to study the polymorphic properties of III has been made by varying the solvent compositions. However, it was found that III does not exhibit

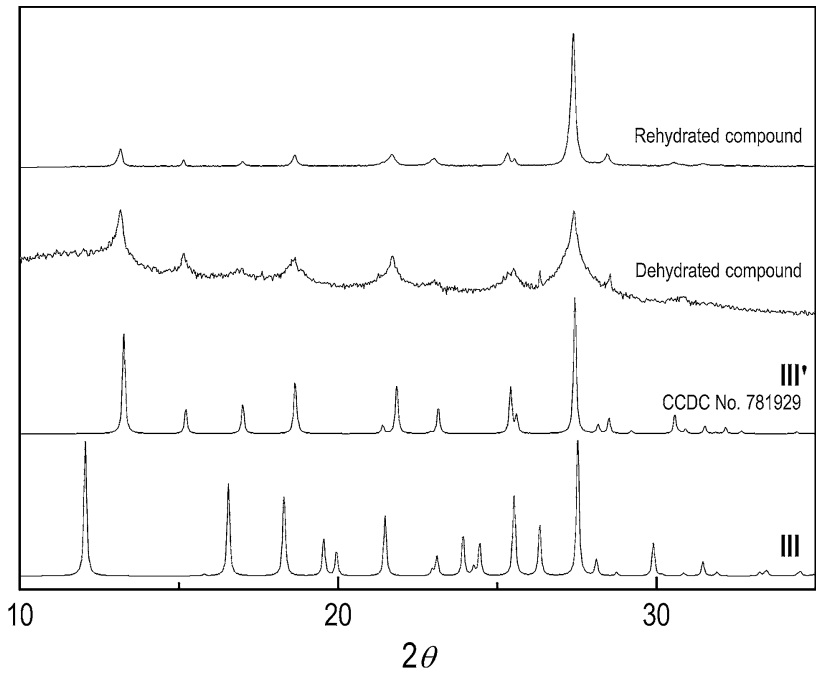

Fig. 11 X-ray powder diffraction patterns showing structural transformation upon removal of coordinating water molecules 
Fig. 12 View of molecular structures of III (a) and III' (b) in the unit cells

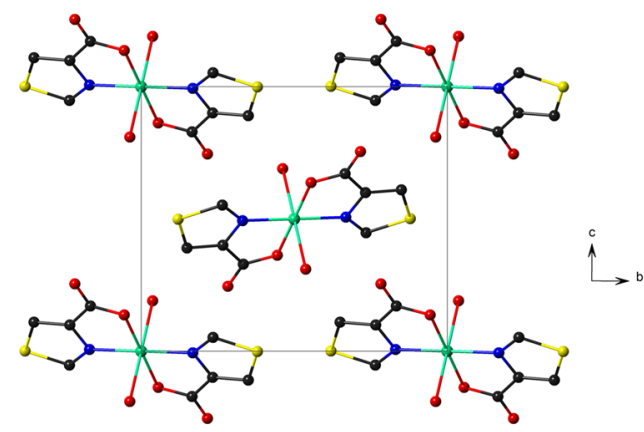

(a)

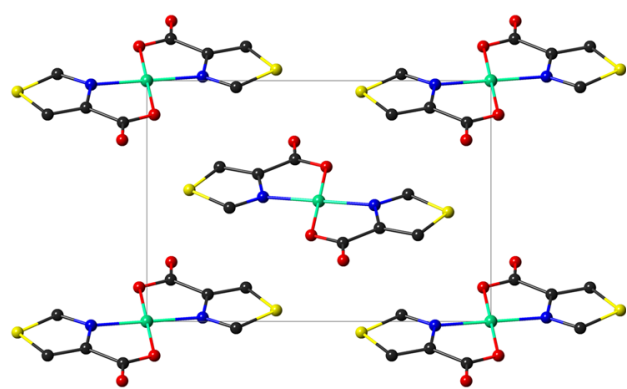

(b) polymorphism in a similar way to I and II. Interestingly, we observed that the solvent compositions play an important role in the crystallization behaviour of copper(II) complex with 4-tza. III was obtained through a mixed methanol/ethanol/water $(3: 3: 9 \mathrm{~mL})$ solvent whereas IV crystallized in a mixed methanol/ethanol/water $(9: 9: 3 \mathrm{~mL})$ solvent. These results indicate the selective crystallization of III and IV. In copious water, this acts as a ligand, but in limited water, it is present unbound but forming hydrogen bonds.

\section{Thermal-induced irreversible structure transformation of III}

Although III is isostructural with I and II, only a single polymorph of III was observed. However, we observe an irreversible structural transformation upon removal of coordinating water ligands. When a crystalline sample of [Cu(4-tza) $\left.)_{2}\left(\mathrm{H}_{2} \mathrm{O}\right)_{2}\right]($ III $)$ is heated at $80{ }^{\circ} \mathrm{C}$ for an hour, all of the aqua ligands are released from the structure giving rise to a dehydration product $\left(\mathbf{I I I}^{\prime}\right)$ which is the known complex [Cu(4-tza $)_{2}$ ] [17], confirmed by the PXRD patterns (Fig. 11) and accompanied by a colour change from turquoise to deep blue. Removal of water happens with minimal structural change (Fig. 12). The crystal of $\left[\mathrm{Cu}(4-\mathrm{tza})_{2}\right]$ bears a close relationship to that of III; these have the same crystal system and space group, monoclinic $P 2_{1} / c$, and very similar unit cell parameters (see Table 1 ). Upon standing for seven days in air that is saturated with water vapour, form III' does not return back to the hydrated form III, but the crystallinity of the sample improves.

Compared with III, the formation of an additional $\mathrm{Cu}-$ $\mathrm{O}_{4 \text {-tza }}$ coordination bond with the bond length of 2.8863(4) $\AA$ takes place along with removal of the the $\mathrm{Cu}-\mathrm{OH}_{2}$ coordination bond with the bond length of 2.3759(16) $\AA$ forming a one dimensional chain running along $a$-axis. Thus, the coordination number of the $\mathrm{Cu}^{\mathrm{II}}$ centre does not change. However, this change in coordination bond affects the hydrogen bonding network in the dehydrated complex compared to the pristine complex. Taking $\left[\mathrm{Cu}(4-\mathrm{tza})_{2}\right.$ $\left(\mathrm{H}_{2} \mathrm{O}\right)_{2}$ ] in III as a node, the hydrogen bonding network can be simplified as a 10-connected uninodal bet net with Schläfli symbol $3^{12} \cdot 4^{28} \cdot 5^{5}$ whereas that of the dehydrated form can be simplified to a 6-connected uninodal pcu alpha-Po primitive cubic net with Schläfli symbol $4^{12} \cdot 6^{3}$ by considering $\left[\mathrm{Cu}(4-\mathrm{tza})_{2}\right]$ as a node [22].

\section{Conclusion}

Thiazole-4-carboxylic acid provides a predictable chelating mode of coordination to first row transition metal ions. We have shown the existence of several complexes with the same bis-chelate and shown the existence of different crystal packings for apparently identical complexes. Thus far, the sulfur atom of the thiazole ring has been almost entirely innocent in the chemistry described. We are currently investigating whether the sulfur atom can coordinate to another metal ion in a similar manner to the coordination of thiophene. The presence of hard donor (carboxylate) and soft donor (sulfur) might allow us to build extended frameworks of hard and soft metal ions for a variety of applications.

\section{Supplementary materials}

CCDC 1486988-1486992 contains the supplementary crystallographic data for this paper. These data can be obtained free of charge from The Cambridge Crystallographic Data Centre via www.ccdc.cam.ac.uk/data request/cif.

Acknowledgments The work is funded by the Thailand Research Fund and the National Research University Project. N. Meundaeng thanks to the Science Achievement Scholarship of Thailand and the Graduate School, Chiang Mai University for the Ph.D. scholarships.

Open Access This article is distributed under the terms of the Creative Commons Attribution 4.0 International License (http://crea tivecommons.org/licenses/by/4.0/), which permits unrestricted use, distribution, and reproduction in any medium, provided you give appropriate credit to the original author(s) and the source, provide a link to the Creative Commons license, and indicate if changes were made. 


\section{References}

1. Blagden N, Davey RJ (2003) Cryst Growth Des 3:873-885

2. Chopra D, Nagarajan K, Guru Row TN (2005) Cryst Growth Des 5:1035-1039

3. Kitamura M (2002) J Cryst Growth 237:2205-2214

4. Haleblian J, McCrone W (1969) J Pharm Sci 58:911-929

5. Varughese S, Kiran KSRN, Solanko KA, Bond AD, Desiraju GR (2011) Chem Sci 2:2236-2242

6. Bilton C, Howard JAK, Laxmi Madhavi NN, Nangia A, Desiraju GR, Allen FH, Wilson CC (1999) Chem Commun 17:1675-1676

7. Jali BR, Baruah JB (2012) Cryst Growth Des 12:3114-3122

8. Yu L (2002) J Phys Chem A 106:544-550

9. Bis JA, Vishweshwar P, Middleton RA, Zaworotko MJ (2006) Cryst Growth Des 6:1048-1053

10. Rogers RD (2003) Cryst Growth Des 3:867

11. Bernstein J, Davey RJ, Henck JO (1999) Angew Chem Int Ed 38:3440-3461

12. Dunitz JD, Bernstein J (1995) Acc Chem Res 28:193-200

13. Connick WB, Henling LM, Marsh RE, Gray HB (1996) Inorg Chem 35:6261-6265
14. Canty AJ, Skelton BW, Traill PR, White AH (1992) Aust J Chem 45:417-422

15. Frija LMT, Pombeiro AJL, Kopylovich MN (2016) Coord Chem Rev 308:32-55

16. Rossin A, Tuci G, Giambastiani G, Peruzzini M (2014) Chem Plus Chem 73:406-412

17. Rossin A, Credico BD, Giambastiani G, Gonsalvi L, Peruzzini M, Reginato G (2011) Eur J Inorg Chem 4:539-548

18. de Meulenaer J, Tompa H (1965) Acta Cryst 19:1014-1018

19. Blessing RH (1995) Acta Cryst A51:33-38

20. Sheldrick GM. SHELXTL version 2014/7. http://shelx.uni-ac. gwdg.de/SHELX/index.php

21. Farrugia LJ (2012) J Appl Cryst 45:849-854

22. Blatov VA, Shevchenko AP, Proserpio DM (2014) Cryst Growth Des 14:3576-3586

23. Iwaoka M, Takemoto S, Tomoda S (2002) J Am Chem Soc 124:10613-10620

24. Mali SM, Schneider TF, Bandyopadhyay A, Jadhav SV, Werz DB, Gopi HN (2012) Cryst Growth Des 12:5643-5648 